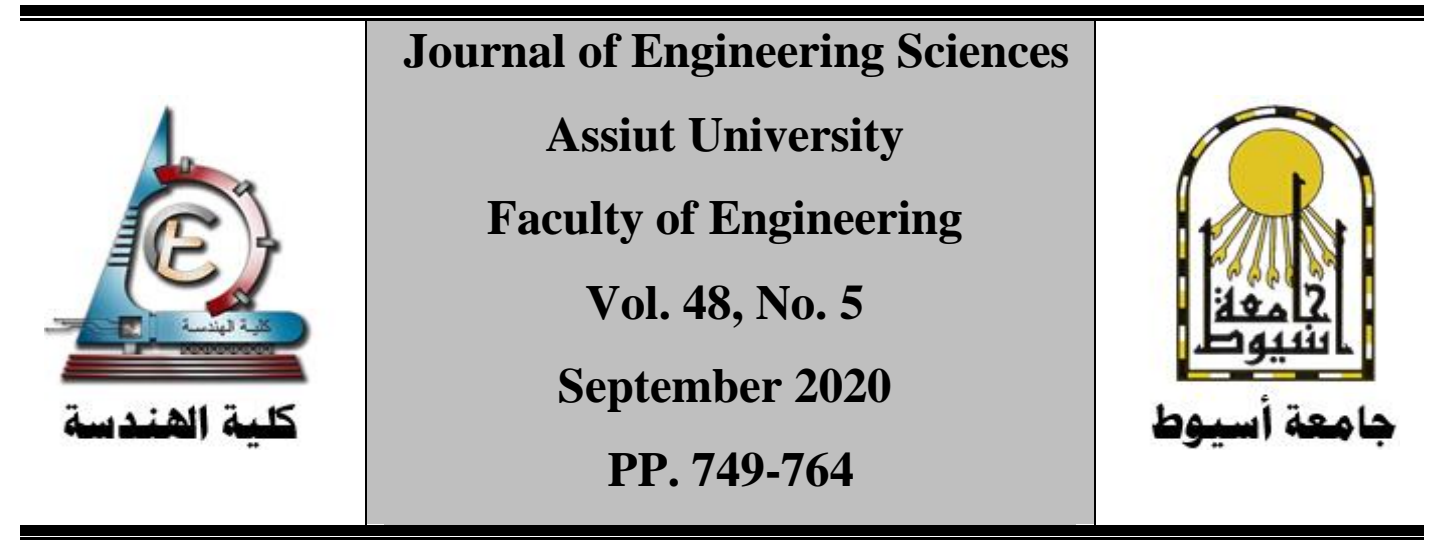

\title{
COMPARISON BETWEEN TWO NUMERICAL MODELS FOR PREDICATION OF HYDRAULICS AND MORPHOLOGICAL CHANGES IN THE RIVER NILE (KM 633 - KM 645 UPSTREAM EI-RODA GAUGE STATION)
}

\author{
Radwa Salama*1, Heba El-Sersawy $^{2}$ \\ ${ }^{1,2}$ Nile research Institute (NRI), National Water Research Center (NWRC), Egypt \\ radwa.salama@yahoo.com
}

Received 14 August 2020; Revised 25 August 2020; Accepted 26 August 2020

\begin{abstract}
The numerical models have effective and necessary tools for rivers hydrological and morphological studies. Numerical models are useful when results are required on scales applicable for hydrological and morphological changes, where velocity and water depth distributions are significant especially in river reaches. In the present study, two well-known hydraulic models are used to simulate the River Nile hydraulics and morphological changes. A sensitivity analysis is carried out for the two models to investigate the features and disadvantages of each model and give recommendations for their further applications. The performance analysis depends on field survey data and simulations. The two models are the SMS modules (FESWMS) model and the (Delft3D) model. The field data were collected for a study reach of $12 \mathrm{~km}$ which is located between $\mathrm{km} 633$ to $\mathrm{km} 645$, measured from El-Roda gauge station. The data included geometric and hydraulic data, that were gathered for calibration and validation of the models. The results indicated that both the SMS module and (Delft3D) model predicted the water surface elevations quite well. The sensitivity analysis showed that (Delft3D) model was more logical to mesh resolution than the SMS module and SMS model presented a better fit for the hydraulic variables. However, Delft3D presented a better fit for velocity and morphological changes.
\end{abstract}


KEYWORDS: Morphological changes; Hydraulics; SMS; Delft3D; River Nile.

\section{Introduction}

Numerical models are increasingly being utilized for simulating the complex hydraulic processes in rivers. Two dimensional (2D) hydrodynamic models have become indispensable tools for water management studies of natural rivers. These models are especially useful for studies where local details of velocity and water depth distributions are important. They normally utilize a representative investigation reach, where the morphologic and hydraulic characteristics can be studied in more details than when considering the entire river as a whole [1]. Morphological changes are mainly established as changing in bed-level, width and slope resulting from scour and deposition processes. As a result of differential gradients normally existing in the transport of water and sediment in the river bed, scour and deposition of the bed and banks are more likely to happen [2].

Morphological analysis of river channels is highly essential for many reasons such as safety of navigation, intake structures locations, and scour around piers and abutments of bridges. It also has an essential task in the planning of the area on the riversides for supportable development [3]. Scour is the result of the erosive action of flowing water around the piers of the Qena bridges. The calculated local scour from the Colarado State University (CSU) equation gave lower results than that calculated from the Froehlich equation [4]. The main processes tracking the transport of particles sediments are the availability of water movement, and sedimentary processes such as flocculation, consolidation, and erosion [5]. The movement of sediments can be predicted by a numerical model that is capable of simulating sediment transport processes and calculating sediment balances. From this overview, it is obvious that different approaches exist to model morphological changes of River Nile and each approach uses its specific methology. A 2D depth averaged numerical model was applied to model the bed morphological changes due to different river flows scenarios downstream new NagaHammadi barrages in addition to sediment processes analysis [6-11].

\section{The main objectives of this study are:}

- Comparing the two hydrodynamic numerical models the SMS modules (FESWMS) and the (Delft3D) model regarding their results, accuracy, computational time, and the relevance of their application for hydraulic and morphological changes of the Nile.

- Preceding a sensitivity analysis for the two models investigating the local hydrological and morphological changes. 
- Briefing the features and disadvantages of the two models and giving recommendations for their further applications.

- Studying the morphological changes in the study reach for different years.

\section{Materials and Methods}

\subsection{Study area}

The numerical models mentioned above were applied on $12 \mathrm{~km}$ which

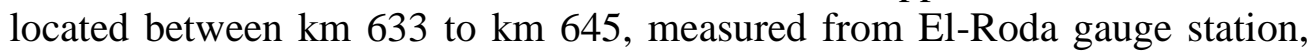
which located in the second reach between Nag Hammdi Barrage at $\mathrm{km}$ 567.500 and Esna Barrage at km 760.340, measured from El-Roda gauge station on Nile River as given in Fig.1.
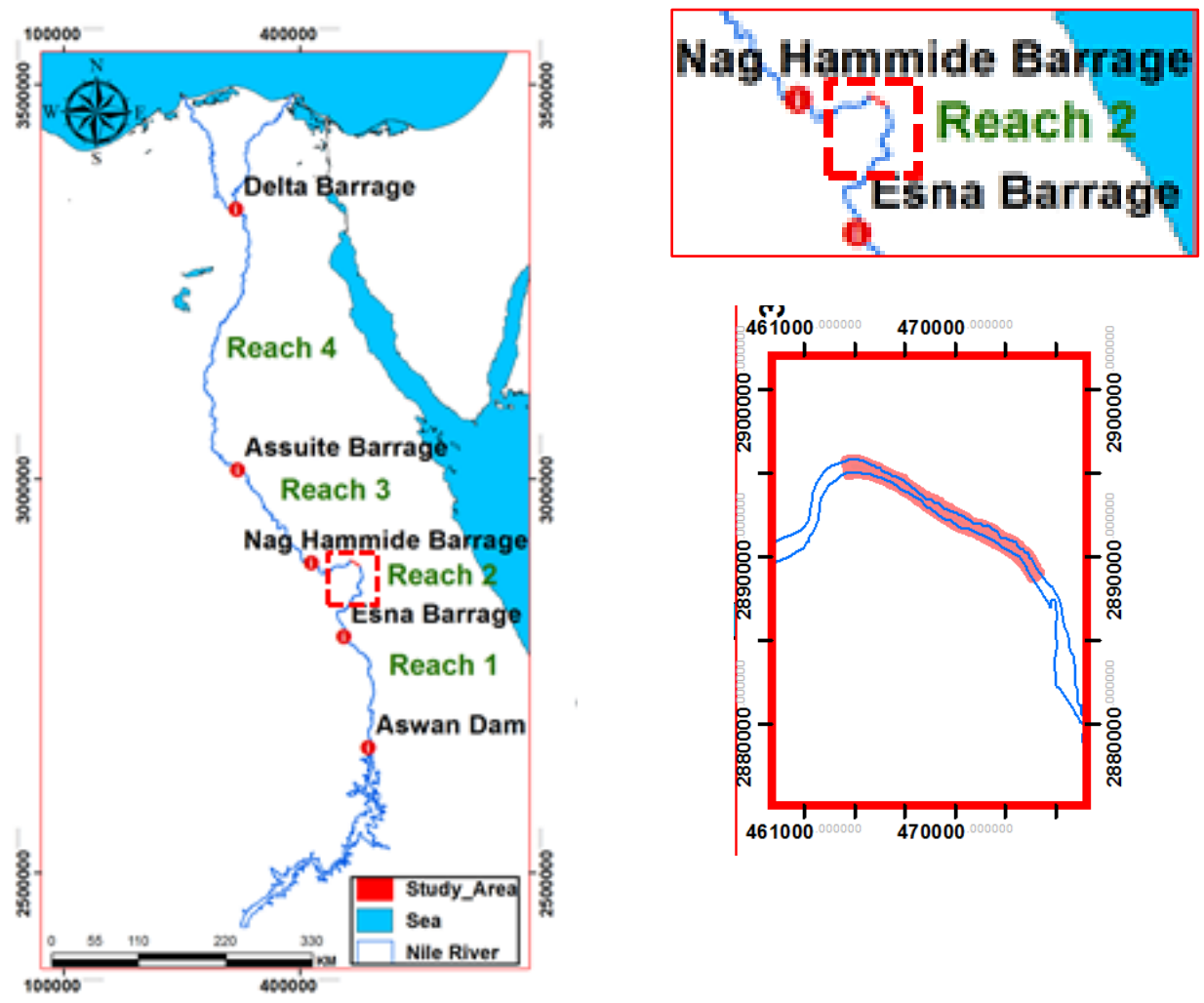

Fig. 1. Schematic sketch for the study reach

\subsection{Methodological Approach}

In order to achieve the objectives of this study, Fig. 2 describes the main steps of research methodology, which include: 
Data Collection: These data included geometric data (cross-sections, bed channel elevation), hydraulic data (water levels, discharge, channel roughness) and sediment particle data (medium diameter, settling velocity).

Numerical Models: Hydraulic models SMS2-D model and the hydrodynamic Delft (3D) model used geometric data, the hydrograph for the water levels, and inflow discharges for simulation and prediction of river hydrological and morphological changes. The measured field data were used for calibration verification, and testing of the models. The Hydraulic models could be employed to simulate the morphological and hydraulic characteristics in the study reach.

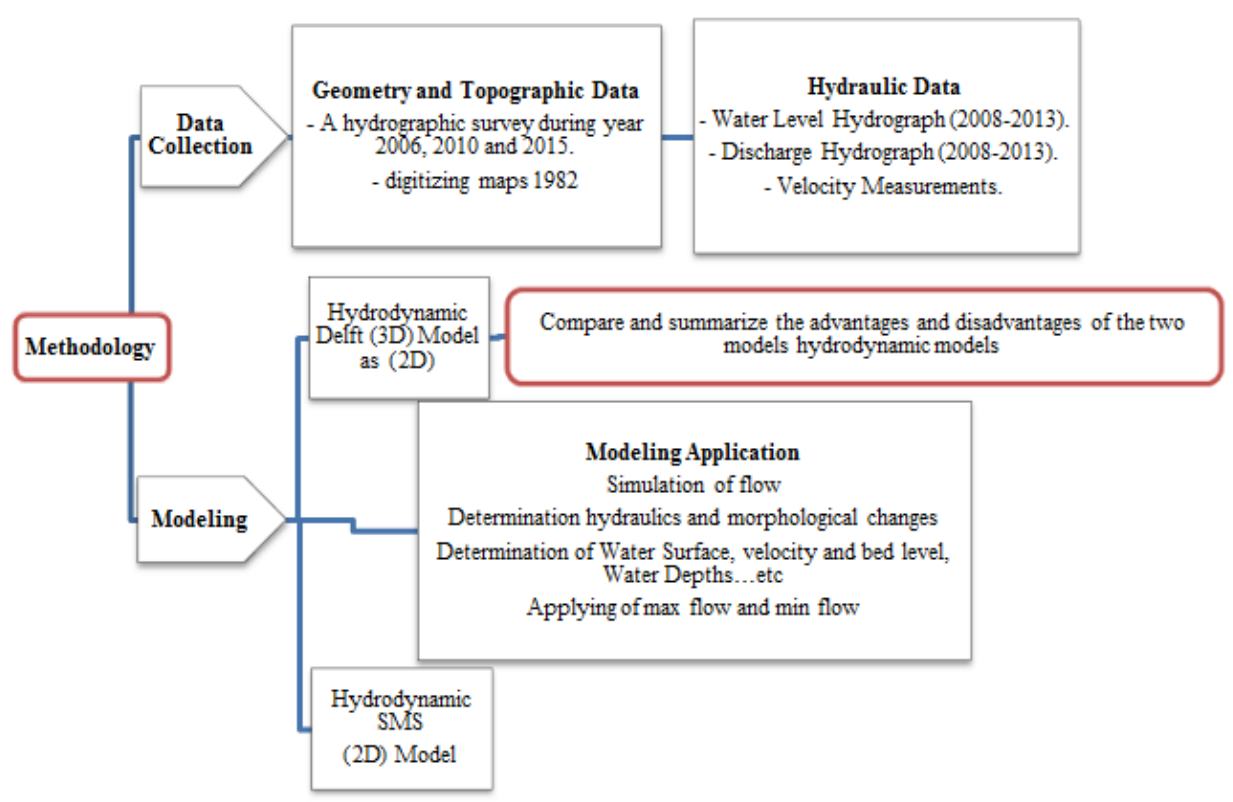

Fig. 2. Flow chart of the research methodology

\section{Data Collection}

2D Hydraulic models require detailed information about the whole river reach. The following data are required to run the models successfully: Bathymetry data describing the channel geometry, boundary conditions (discharge and water level), channel roughness coefficients, and eddy viscosity values.

\subsection{Bathymetric data}

A hydrographic survey of the study area excuated by the Nile Research Institute "NRI" of the National Water Research Center for different years. 
The survey was excuated along the study reach, between the two banks of the river as given in Fig.3.

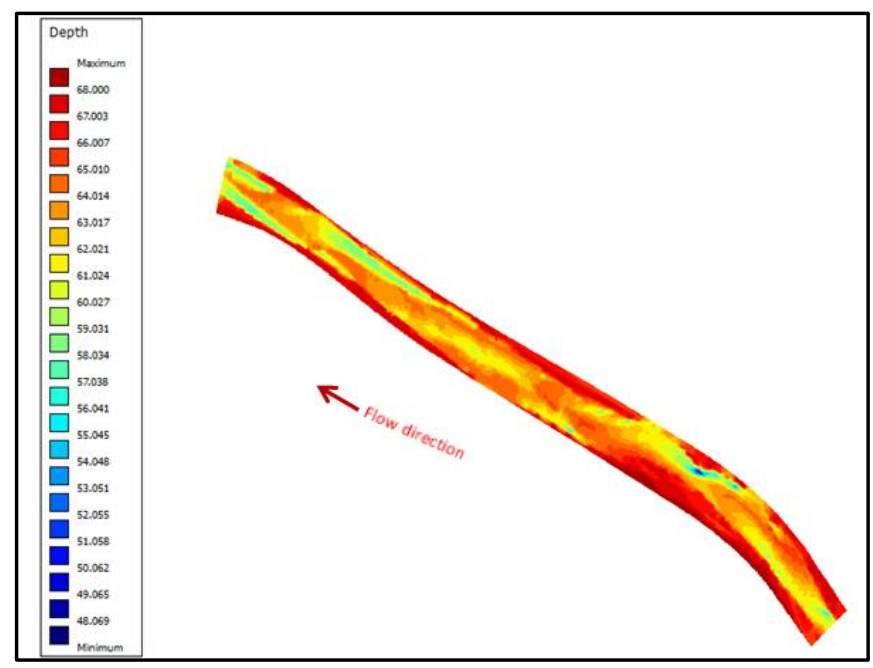

Fig. 3. Riverbed elevation

\subsection{Hydrological data}

The water levels were recorded along Qena station and max and min released discharges downstream Esna Barrage during the period from years 2008 to 2013 as shown in Fig. 4 ( $a$ and b).

\section{Model Description}

\subsection{SMS (2D-Model) description}

The Surface Water Modeling System (SMS) is used to simulate flow in the study reach. The SMS was initially developed by the Engineering Computer Graphics Laboratory at Brigham Young University in 1998. The SMS is the interface of the FESWMS, which is a depth-averaged flow and sediment transport model. The finite element method is used to solve the governing differential equations that describe the $2 \mathrm{D}$ depth-averaged surface water flow [12], as given in followings equations [equations (1)-(3)]:

$$
\begin{aligned}
& \frac{\partial(H U)}{\partial t}+\frac{\partial}{\partial x}\left\{\beta_{u u} H U U+\left(\cos \alpha_{x} \cos \alpha_{z}\right)^{2} \frac{1}{2} g H^{2}\right\}+\frac{\partial}{\partial y}\left(\beta_{u v} H U V\right)+ \\
& \cos \alpha_{x} g H \frac{\partial z_{b}}{\partial x}-\Omega H V+\frac{1}{\rho}\left[\tau_{b x}-\tau_{s x}-\frac{\partial\left(H \tau_{x x}\right)}{\partial x}-\frac{\partial\left(H \tau_{x y}\right)}{\partial y}\right]=0
\end{aligned}
$$




$$
\begin{aligned}
& \frac{\partial(H V)}{\partial t}+\frac{\partial}{\partial y}\left\{\beta_{v v} H V V+\left(\cos \alpha_{y} \cos \alpha_{z}\right)^{2} \frac{1}{2} g H^{2}\right\}+\frac{\partial}{\partial y}\left(\beta_{u v} H V U\right)+ \\
& \cos \alpha_{y} g H \frac{\partial z_{b}}{\partial y}-\Omega H V+\frac{1}{\rho}\left[\tau_{b y}-\tau_{s y}-\frac{\partial\left(H \tau_{y x}\right)}{\partial x}-\frac{\partial\left(H \tau_{y y}\right)}{\partial y}\right]=0 \\
& \frac{\partial H}{\partial t}+\frac{\partial(H U)}{\partial x}+\frac{\partial(H V)}{\partial y}=\mathrm{q}
\end{aligned}
$$

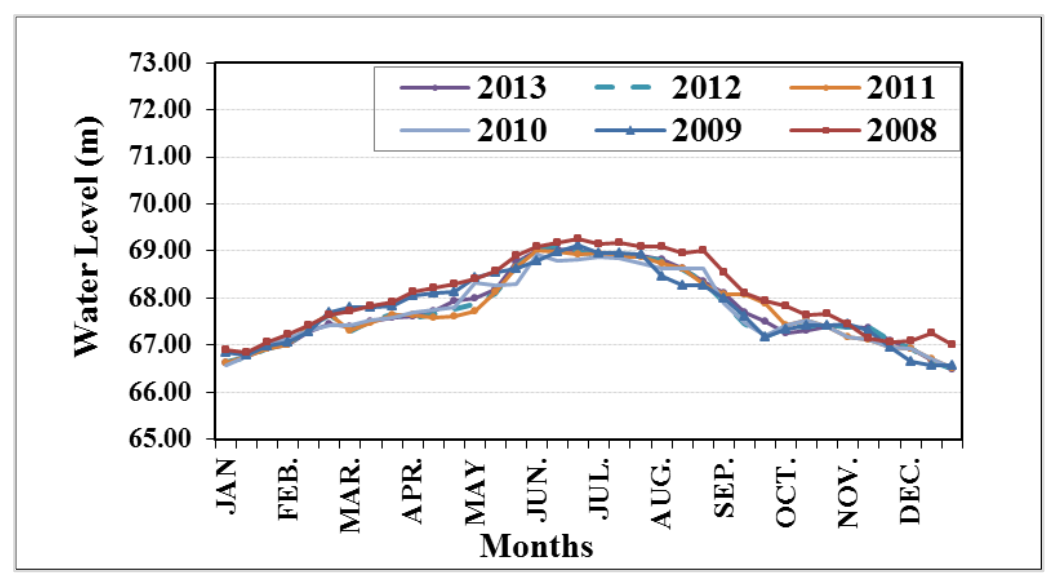

a)

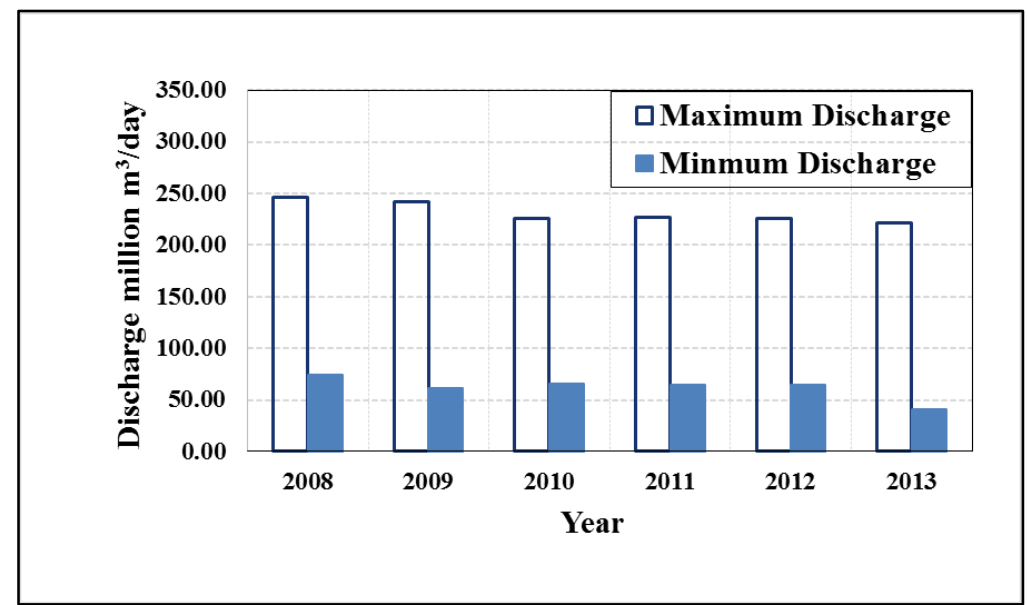

b)

Fig. 4. (a) Water levels at Qena gauge station; (b) Max and min discharges downstream Esna Barrage for years (2008) through (2013) 
Where $\mathrm{H}=$ water depth; $\mathrm{z}=$ vertical direction; $\mathrm{z}_{\mathrm{b}}$ is the bed elevation; $\mathrm{z}_{\mathrm{s}}=\mathrm{z}_{\mathrm{b}}$ $+\mathrm{H}=$ water surface elevation; $\mathrm{U}=$ horizontal velocity in the $\mathrm{x}$ direction; and $\mathrm{V}=$ horizontal velocity in the $\mathrm{y}$ direction; $\beta_{u u}, \beta_{u v}$, and $\beta_{v v}=$ momentum flux correction coefficients that account for the variation of velocity in the vertical direction; $\alpha_{\mathrm{x}}=\arctan \left(\frac{\partial Z_{b}}{\partial x}\right), \alpha_{\mathrm{y}}=\arctan \left(\frac{\partial Z_{b}}{\partial y}\right), \alpha_{z}=\operatorname{arcos}(1-\cos 2 \alpha \mathrm{x}$ - $\cos 2 \alpha \mathrm{y}) ; \mathrm{g}=$ gravitational acceleration; $\Omega=$ Coriolis parameters; $\rho=$ water mass density, which is considered constant; $\tau_{b x}$ and $\tau_{b y}=$ bed shear stresses acting in the $\mathrm{x}$ and $\mathrm{y}$ directions, respectively; $\tau_{s x}$ and $\tau_{s y}=$ surface shear stresses acting in the $\mathrm{x}$ and $\mathrm{y}$ directions, respectively; and $\tau_{x x}, \tau_{x y}, \tau_{y x}$, and $\tau_{y y}=$ shear stresses caused by turbulence; $\mathrm{q}=$ unit source (inflow) or a unit sink (outflow) term, $\mathrm{t}=$ time and $\mathrm{u}^{*}=$ shear velocity which can be calculated by using either smooth wall log velocity profile, or the Manning shear stress equation.

\subsection{Delft (3D-FLOW) Description}

To simulate the river flow of the study reach, the Delft3D model was applied to simulate the flow velocity, by a set of mathematical equations based on the conservation of mass, momentum. This model can be used with good accuracy in the field of hydrodynamics [13]. Delft3D -flow is the hydrodynamic module of Delft3D, which consists of several modules. Delft3D-FLOW solves the Navier Stokes equations for an incompressible fluid, under the shallow water and the Boussinesq assumptions. The numerical method of Delft3D-FLOW is based on finite differences.

The set of partial differential equations in combination with an appropriate set of initial and boundary conditions are solved on a finite difference grid [14]. The model solves the depth-averaged continuity equation and the momentum equations in horizontal directions. These equations [equations (4)-(6)] are shown as follows:

$\frac{\partial \zeta}{\partial \mathrm{t}}+\frac{\partial \mathrm{HU}}{\partial \mathrm{x}}+\frac{\partial \mathrm{HV}}{\partial \mathrm{y}}=0$

The depth-averaged momentum equations in two dimensions (in $\mathrm{x}$ - and $\mathrm{y}$ directions respectively) are:

$$
\begin{aligned}
& \frac{\partial \mathrm{U}}{\partial \mathrm{t}}+\mathrm{U} \frac{\partial \mathrm{U}}{\partial \mathrm{x}}+\mathrm{V} \frac{\partial \mathrm{U}}{\partial \mathrm{y}}=-\mathrm{g} \frac{\partial \zeta}{\partial \mathrm{x}}+\mathrm{fV}+\mathrm{V}_{\mathrm{H}}\left[\frac{\partial^{2} \mathrm{U}}{\partial \mathrm{x}^{2}}+\frac{\partial^{2} \mathrm{U}}{\partial \mathrm{y}^{2}}\right]-\frac{\mathrm{gU} \sqrt{\mathrm{U}^{2}+\mathrm{V}^{2}}}{\mathrm{HC}^{2}} \\
& \frac{\partial \mathrm{V}}{\partial \mathrm{t}}+\mathrm{U} \frac{\partial \mathrm{V}}{\partial \mathrm{x}}+\mathrm{V} \frac{\partial \mathrm{V}}{\partial \mathrm{y}}=-\mathrm{g} \frac{\partial \zeta}{\partial \mathrm{y}}+\mathrm{fU}+\mathrm{V}_{\mathrm{H}}\left[\frac{\partial^{2} \mathrm{~V}}{\partial \mathrm{x}^{2}}+\frac{\partial^{2} \mathrm{~V}}{\partial \mathrm{y}^{2}}\right]-\frac{\mathrm{gV} \sqrt{\mathrm{U}^{2}+\mathrm{V}^{2}}}{\mathrm{HC}^{2}}
\end{aligned}
$$


Where: $\zeta=$ water level according to reference level $(\mathrm{m}), \mathrm{H}=$ total water depth $(\mathrm{m}), \mathrm{U}$ and $\mathrm{V}=$ depth-averaged velocity in $\mathrm{x}$ - and $\mathrm{y}$-direction $(\mathrm{m} / \mathrm{s})$ respectively, $\mathrm{g}=$ acceleration due to gravity $\left(\mathbf{m}^{2} / \mathrm{s}\right), \mathrm{f}=$ Coriolis parameter $(1 / \mathrm{s}), \mathbf{V}_{\mathbf{H}}=$ horizontal eddy viscosity $\left(\mathbf{m}^{2} / \mathrm{s}\right), \mathrm{C}=$ Chézy coefficient $\left(\mathbf{m}^{\mathbf{1} / 2} / \mathrm{s}\right)$.

\subsection{Model preparation}

During the process of establishing the two numerical models to represent a given study area.The reach length was about $12 \mathrm{~km}$ along the shoreline; The average grid size for Delft (3D) model was $\left(40 \mathrm{~m}^{*} 40 \mathrm{~m}\right)$ used in the model and is presented in Fig. 5. For (SMS) model the average grid size of the mesh with the highest resolution was $25 \mathrm{~m}$ as shown in Fig. 6. The inflow boundary condition of the study area for two models Delft3D and SMS model were defined as the max and min released discharges at downstream Esna Barrage discharges. The outflow boundary condition was used as water level at end of the study reach.
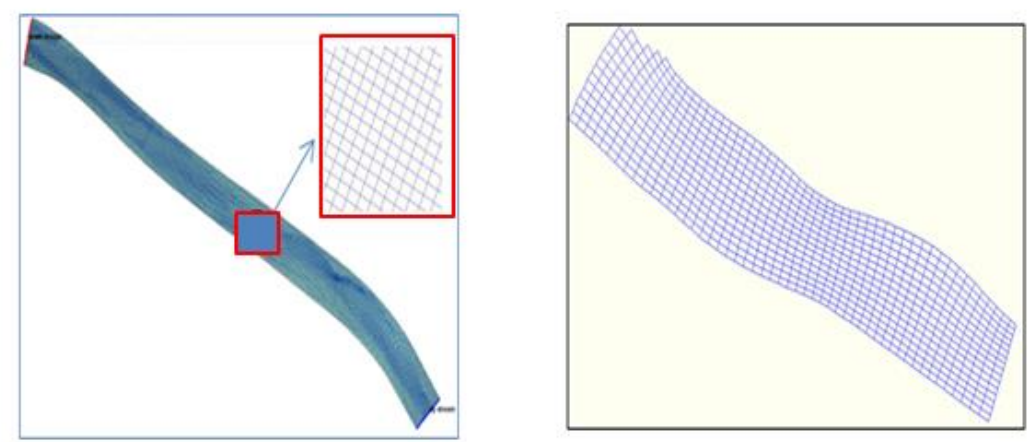

Fig. 5. Grids used in (Delft3D) model. Fig. 6. Grids used in (SMS) model.

\subsection{Model calibration and Verification}

During the process of establishing two numerical models to represent the study reach, calibration is performed to ensure adequate prediction of hydrodynamic conditions. The calibration and the verification of the two models depend on the amount and quality of topographic, accuracy of the grid and hydraulic collected data such as velocity distributions, water-surface elevation, flow rates, and bed roughness. For the calibration process, the two models were applied for the river discharge 90 million. $\mathrm{m}^{3} /$ day at downstream Esna Barrage which is corresponding to the water level $(65.90 \mathrm{~m})$ at the end of the study reach. Iterative adjustments of the element/nodal friction Manning's $\mathrm{n}$ value for roughness coefficient varied between $(0.025)$ and (0.045). The results of the simulated water surface elevations for the study reach were compared with the available gauge station measurements as given in Fig.7. It can be concluded that both Delft3D and SMS show a good 
comparison between the measured water surface elevations and the predicted ones but the output of the Delft3D model shows better representation between measured and predicted water surface elevations.

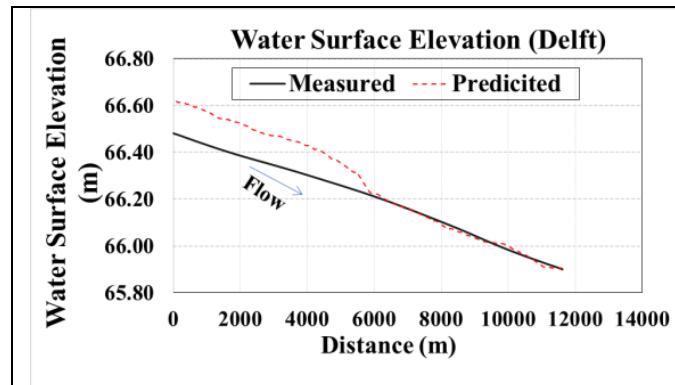

(a)

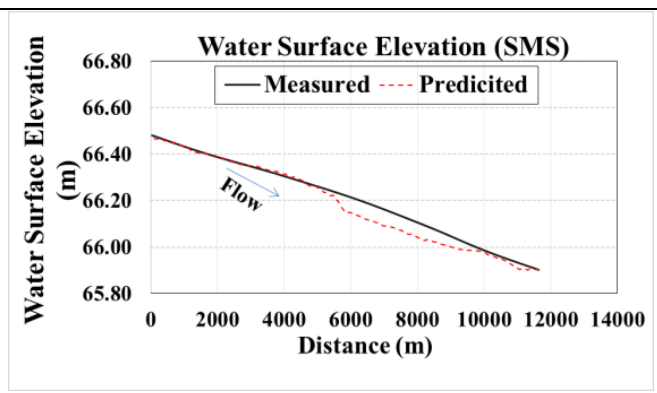

(b)

Fig.7. Comparison between measured and predicted water surface elevations along the study reach (a) Delft3D model and (b) SMS model

A calibration between the field measured velocities and predicted profiles of velocity obtained from the two hydrodynamic models at four cross-sections at kms. 640.439, 640.350, 637.789, and 637.639. Fig. (8) shows the simulated runs and the predicted ones using the two models. The field observation water level simulations excuated using $(65.90 \mathrm{~m})$ and discharge 90 million. $\mathrm{m}^{3} /$ day.

The two measures (coefficient of determination $\left(\mathrm{R}^{2}\right)$ and Root Mean Square Error (RMSE)) are widely accepted [15] and are taken into consideration for this study. The Root Mean Square Error (RMSE) is a frequently used as a measure for quantifying the differences between the measured values and the corresponding calculated values given by a model as in (Fig.9). The RMSE of a model prediction with respect to the estimated variable $X_{\text {model }}$ is defined as the square root of the mean squared error. Where $\bar{X}$ obs is observed values and $\bar{X}$ model are modeled values at time/place $\mathrm{i}$ and $\mathrm{N}$ is the number of points as shown in Table 1. The two statistical measures $\left(\mathrm{R}^{2}\right)$ and (RMSE) were computed to quantify the model results performance for the observed and measured velocity values. The results of the SMS model show more representatives' accuracy between measured and model velocities. 
JES, Assiut University, Faculty of Engineering, Vol. 48, No. 5, September 2020, pp. 749-764

Table: 1. Statistical Measure Methods

\begin{tabular}{|c|c|c|c|c|c|}
\hline Parameter & Range & $\begin{array}{c}\text { Optimal } \\
\text { value }\end{array}$ & Expression & Model & $\begin{array}{c}\text { Calculated } \\
\text { Value }\end{array}$ \\
\hline $\mathrm{R}^{2}$ & $0-1$ & 1 & $\left(\frac{\sum_{i=1}^{n}\left(X_{o b s, i}-\bar{X} \text { obs }\right)\left(X_{\text {model }, i}-\bar{X} \text { model }\right)}{\sqrt{\sum_{i=1}^{n}\left(X_{o b s, i}-\bar{X} \text { obs }\right)^{2}} \sqrt{\sum_{i=1}^{n}\left(X_{\text {model }, i}-\bar{X} \text { model }\right)^{2}}}\right)^{2}$ & $\begin{array}{c}\text { SMS } \\
\text { model }\end{array}$ & 0.84 \\
\cline { 5 - 6 } & Relft & model & 0.66 \\
\hline RMSE & $0-\infty$ & 0 & $\sqrt{\frac{\sum_{i=1}^{n}\left(X_{o b s, i}-X_{\text {model }, i}\right)^{2}}{N}}$ & $\begin{array}{c}\text { SMS } \\
\text { model }\end{array}$ & 0.21 \\
\cline { 5 - 6 } & & & $\begin{array}{c}\text { Delft } \\
\text { model }\end{array}$ & 0.11 \\
\hline
\end{tabular}

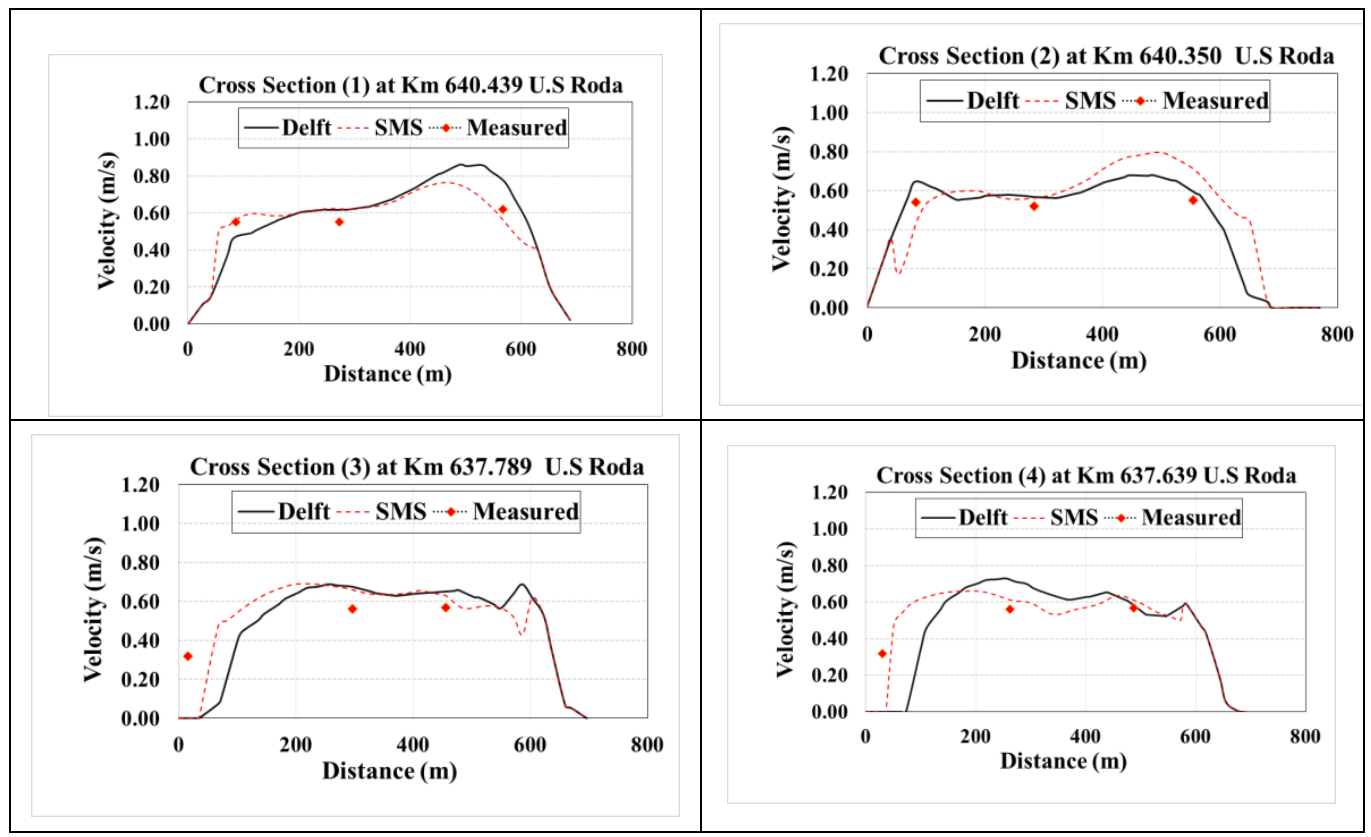

Fig.8. Flow velocity distribution at cross-sections from (1) to (4)

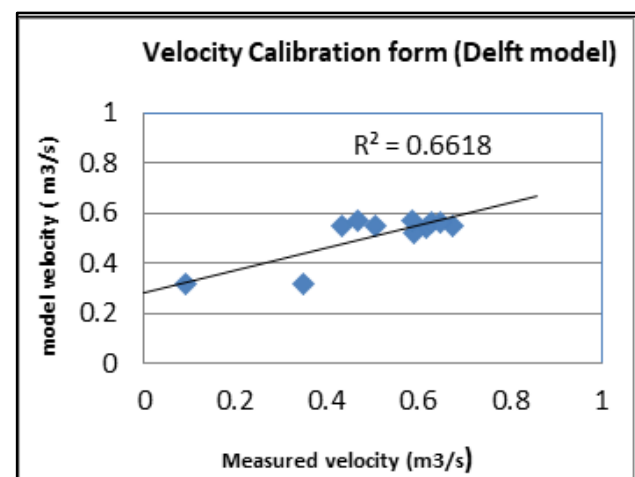

(a)
Velocity Calibration form (SMS model)

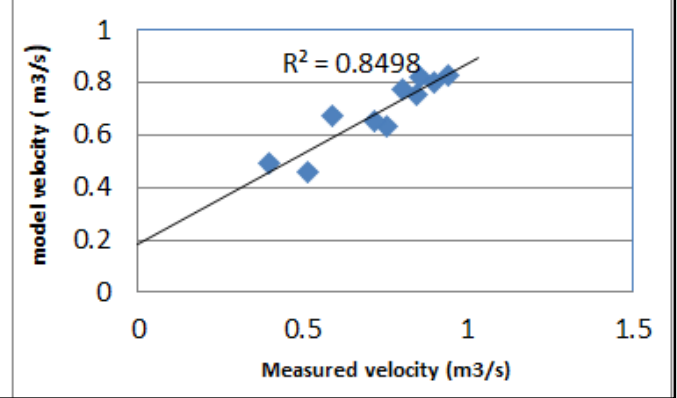

(b)

Fig. 9. Simulated versus measured velocities a) Delft 3D model and (b) SMS model 


\section{Results and Discussion}

The study area is devoted to the presentation and analysis of simulation results. So, comparative studies were implemented between extracted profiles from the two hydrodynamic models. Different cross sections describe each of the simulations performed in support of this study with both the Delft and SMS hydrodynamic models. The hydraulic changes simulations, using year 2010 which available for bathymetry data, water level and discharge and boundary conditions for different scenarios is used as Table 2. The aim of comparative studies is to determine the benefits and limitations of the two hydrodynamic models and propose eventually the most suitable software for accurate modeling for hydrological changes.

Table: 2. Boundary conditions.

\begin{tabular}{|c|c|c|}
\hline Flow case & $\begin{array}{c}\text { Discharge } \\
\left(\text { million.m }^{\mathbf{3} / \text { day })}\right.\end{array}$ & Water level $(\mathbf{m})$ \\
\hline Minimum & 41 & 65.88 \\
\hline Maximum & 246 & 69.88 \\
\hline
\end{tabular}

\subsection{Hydraulic changes analysis}

The two models' outputs for different scenarios with respect to their water surface elevation and velocities of the two models were considered as comparison criteria.

\subsubsection{Water surface elevation}

Comparisons of predicted water surface elevations computed by two models for cases of min. and max. discharges are shown in Figs.10 and 11.

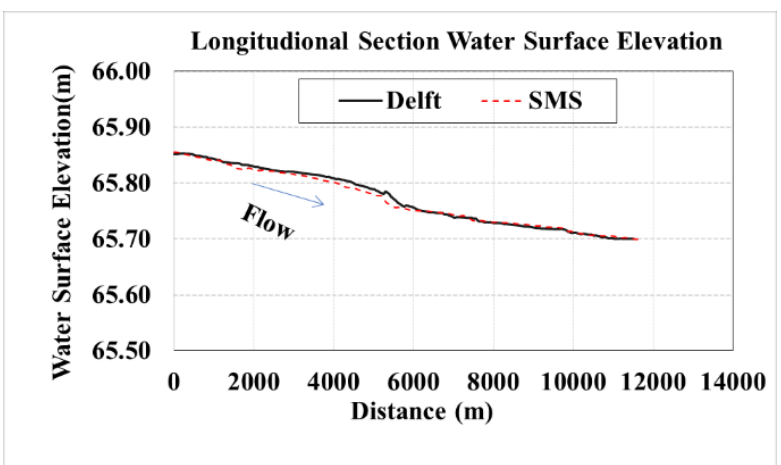

Fig.10. Comparison between predicted water surface elevation by the two models along the study reach for min. discharge 


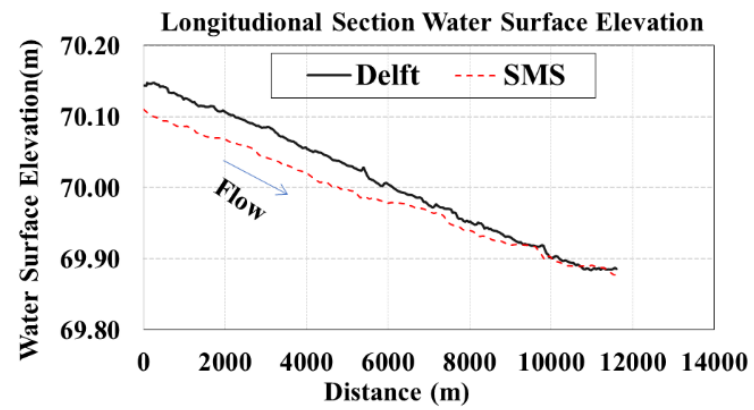

Fig.11. Comparison between predicted water surface elevation by the two models along the study reach for max. discharge

\subsubsection{Velocity distribution}

Comparisons between the predicted flow velocity by the two models and the available measured field data at cross-sections for min. and max. discharges are presented in Figs. 12 and 13. It can be seen that the simulation outputs of the flow velocity of the two models and filed data are quite comparable. No general trend of over or underestimation by one of the models was seen. The maximum difference seen is because of the difference in computing the dry cells especially near boulders. For more than $90 \%$ of the cells, the velocities match quite well. SMS model outputs are more acceptable for filed data than Delft model outputs for the case of min. and max discharge.

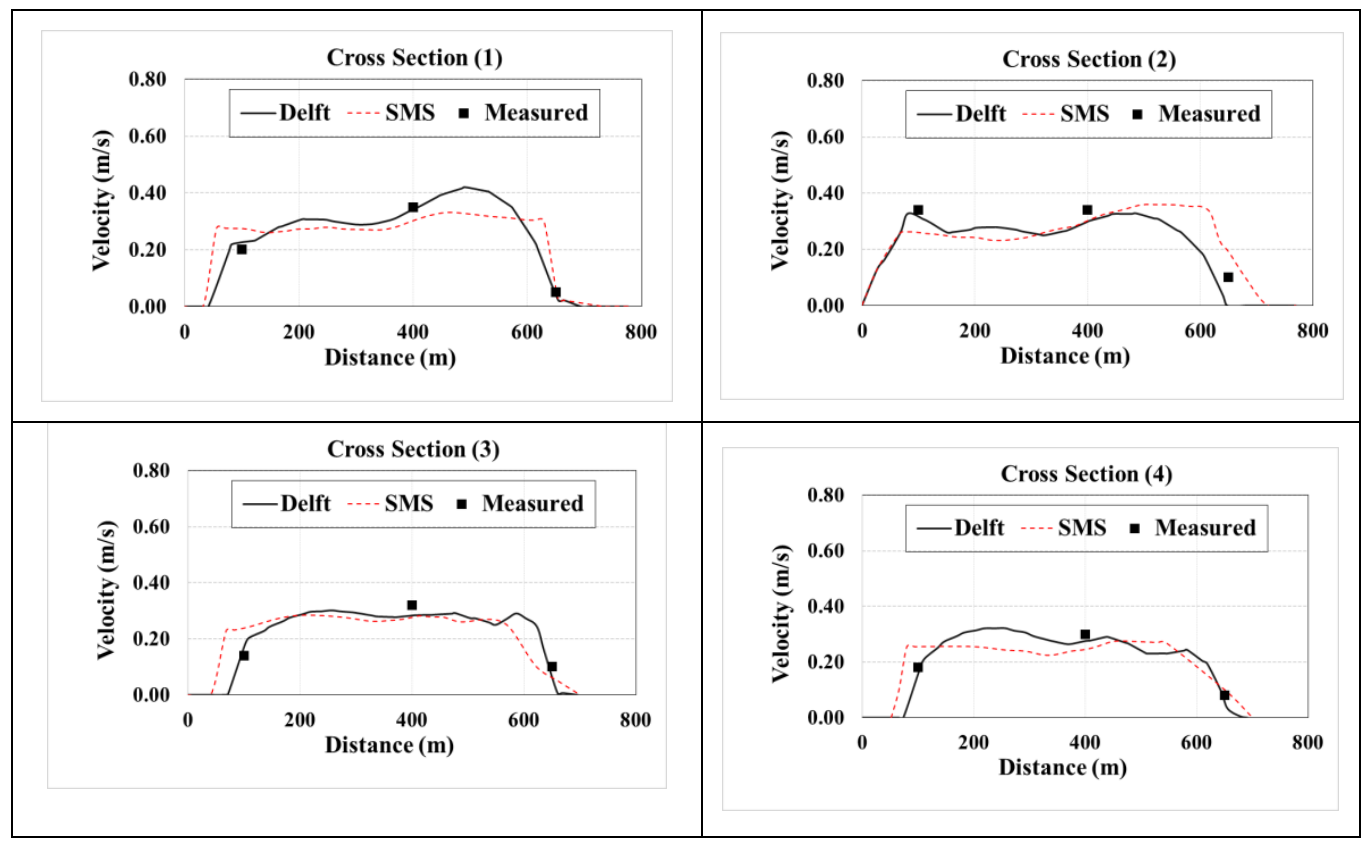

Fig.12. Predicted and measured velocities for min. discharge 
Radwa Salama and Heba El-Sersawy, Comparison Between two Numerical Models for Predication...

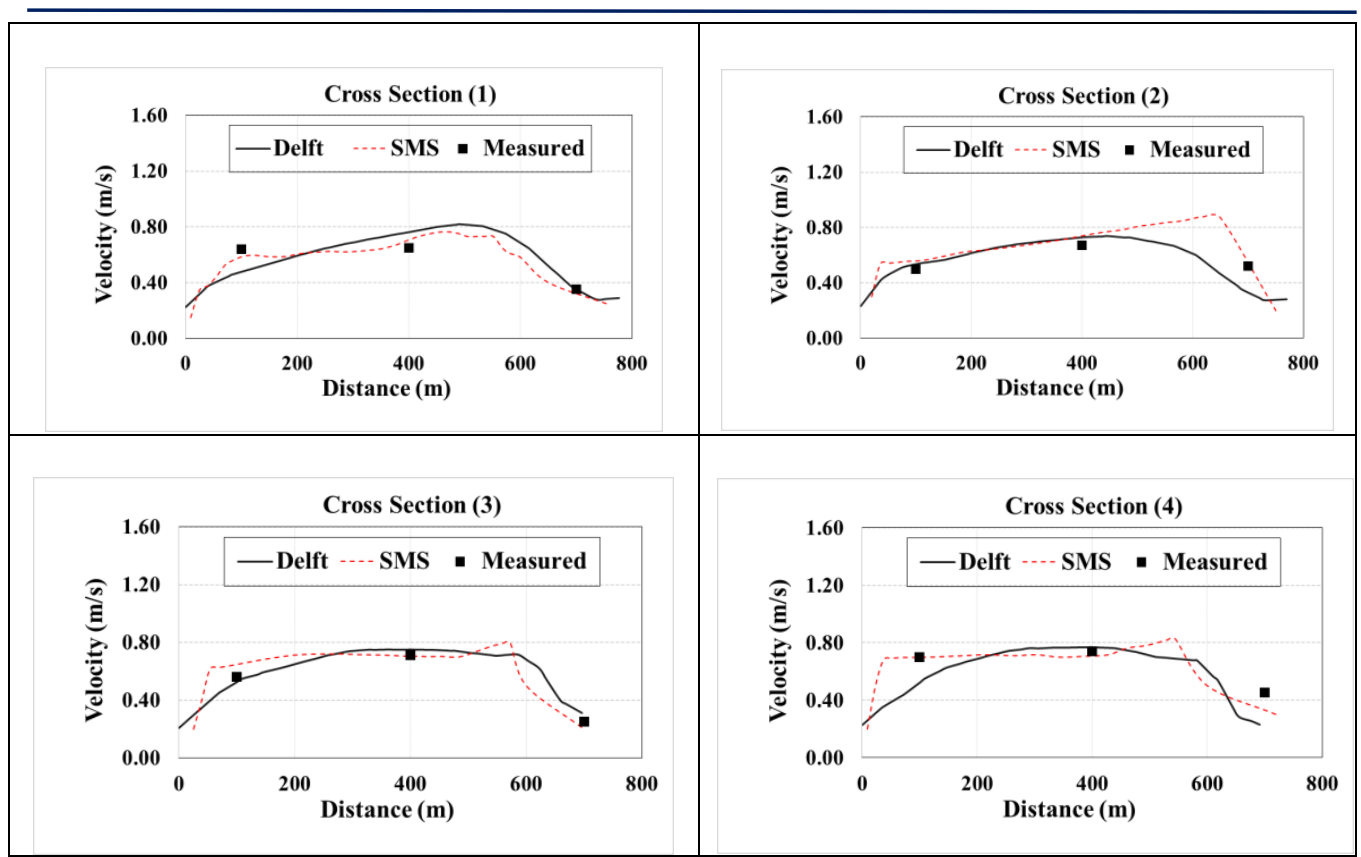

Fig.13. Predicted and measured velocities for max. discharge

\subsection{Geometric bed level analysis}

The survey was excuated along the study area, between the two banks of the river. A comparison of bed level along the study reach during years 1982, 2006, 2010 and 2015 for cross-sections at kms. 640.439 and 637.639 U.S Roda is presented in Fig.14. The figure shows that the study area was exposed to deposition at right hand bank of cross-section and the occurrence of erosion of bed elevation at left hand bank of cross-section.

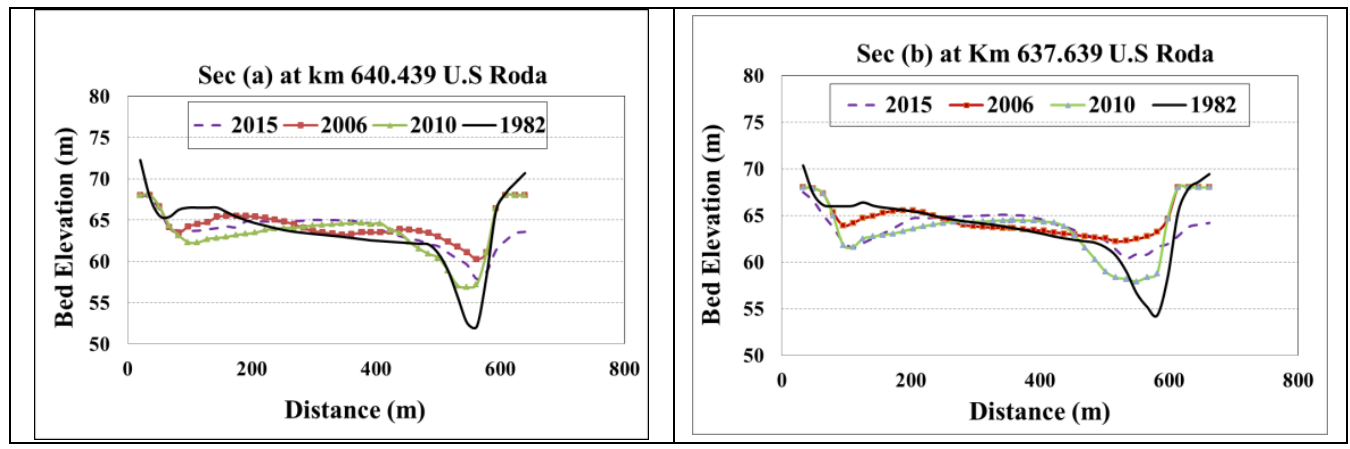

Fig.14. Riverbed elevations at cross-sections (a) and (b) for years 1982, 2006, 2010 and 2015

The current study devoted to the presentation morphological changes and reliability of the topographic data insertion into the two hydrodynamic 
models. So, comparative studies were excuated between extracted profiles from the two numerical models and those measured data for year 2015 from the available measured topographic data presented in Fig. 15.

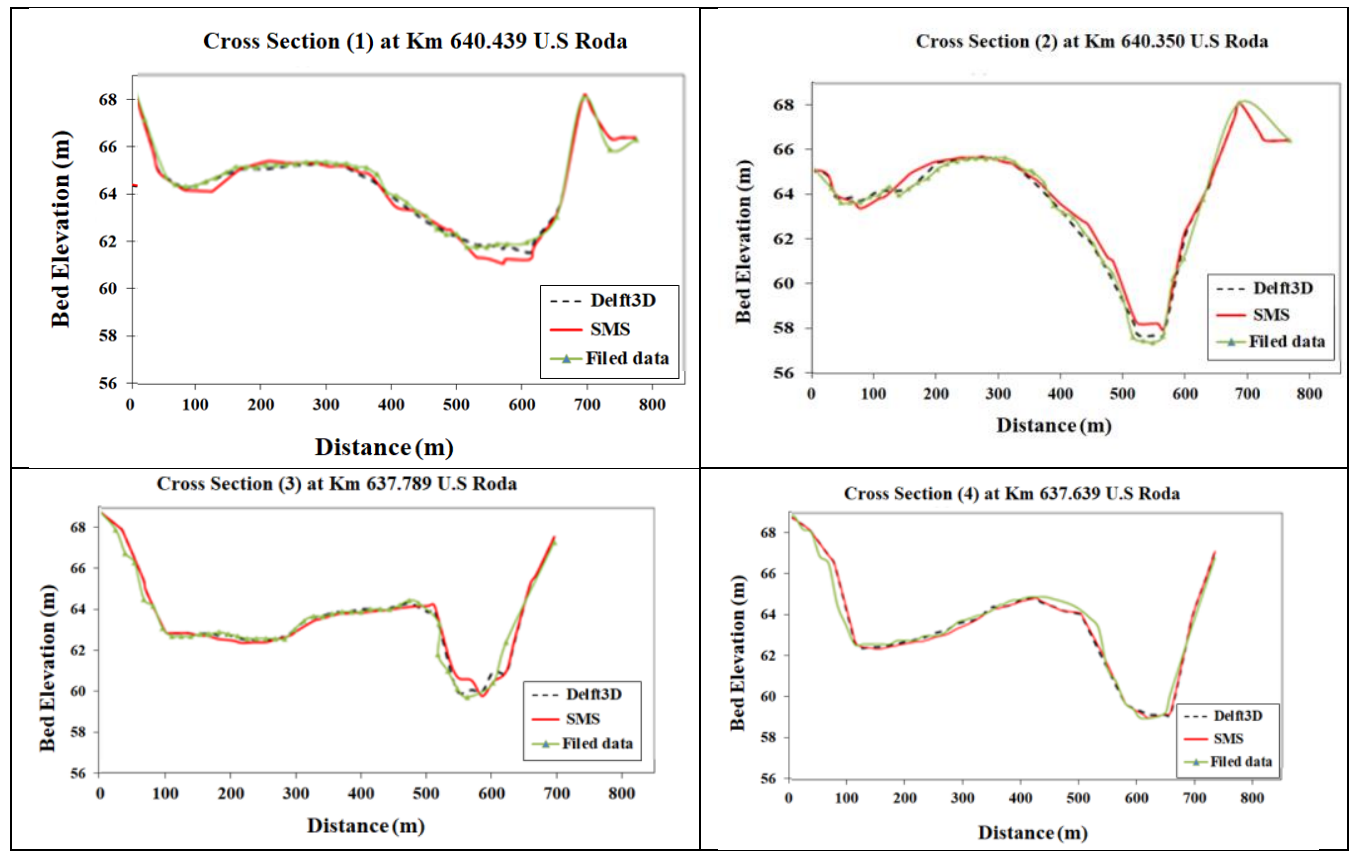

Fig.15. Comparison between geometric river bed levels at different cross-sections.

After reviewing the previous cross-sections it is clear that Delft3D presented a better fit to geometric bed level sections than the SMS model to that measured topographic show from The two statistical measures $\left(\mathrm{R}^{2}\right)$ and (RMSE) were computed to quantify the model results performance for the observed and filed data values as shown in Table 3.

Table (3) Statistical measure methods

\begin{tabular}{|c|c|c|c|c|c|}
\hline cases & Parameter & Range & Optimal value & Model & Calculated Value \\
\hline \multirow{4}{*}{ Min } & \multirow{2}{*}{$\mathrm{R}^{2}$} & \multirow{2}{*}{$0-1$} & \multirow{2}{*}{1} & SMS model & 0.87 \\
\hline & & & & Delft model & 0.56 \\
\hline & \multirow{2}{*}{ RMSE } & \multirow{2}{*}{$0-\infty$} & \multirow{2}{*}{0} & SMS model & 0.11 \\
\hline & & & & Delft model & 0.31 \\
\hline \multirow{4}{*}{ Max } & \multirow{2}{*}{$\mathrm{R}^{2}$} & \multirow{2}{*}{$0-1$} & \multirow{2}{*}{1} & SMS model & 0.91 \\
\hline & & & & Delft model & 0.71 \\
\hline & \multirow{2}{*}{ RMSE } & \multirow{2}{*}{$0-\infty$} & \multirow{2}{*}{0} & SMS model & 0.21 \\
\hline & & & & Delft model & 0.33 \\
\hline
\end{tabular}




\section{Conclusions}

The main aim of this paper was to compare two hydrodynamic models (Delft3D and SMS) models with reference to their outputs, accuracy, and computation time, and to do a sensitivity analysis for the two models for investigating the effects of mesh resolution and exclusion of rock from the scatter data on model results. SMS model is necessary to model the hydraulic variables at the calibration process and is not so suitable for predicting the changes in bed morphology and in the segments of the river between the cross-sections monitoring. However, Delft3D presented a better fit for morphological changes. It is recommended to extend the model simulations with sedimentation and predict the morphology changes and to study the sedimentary processes in more detail.

\section{References}

[1] Gezahegn, H.,( 2008).“Comparison Of 2D Hydrodynamic Models In River Reaches Of Ecological Importance: Hydro - AS-2D and SRH-W,"WAREM Univ.Stuttgart Auslandsorientierter, p. 96.

[2] Ali, A.,( 2007). "Utilizing Sedimentation Deflector System For Reducing Sedimentation At El-Kurimat Power Station Intake, Egypt," Elev. Int. Water Technol. Conf. IWTC11 2007 Sharm El-Sheikh, Egypt, pp. 471- 485.

[3] Ahmad, P. and Simonovic, S.,( 1999). "Role Of A Coupled GIS-2-D Hydrodynamic Model In A Decision Support System for Flood Management," Proc. CWRA Conf. Red River Flooding - Decreasing Our RisksOctober 27-28, Winnipeg, Manitoba. Hydrol.

[4] Salama, R., (2018). "Evaluation of Local Scour around Bridge Piers (Qena Bridge as A Case Study)" International Water Technology Journal, IWTJ, Vol. 8 -No.4, pp. 118-128.

[5] Leussen, V.,( 1991). "Sediment Transport Under Tidal Action," Geo-Marine Letters, pp 119-126, Springer - Verlag, New York .

[6] Sattar, A., (2016). "Bed Morphological Changes Of The Nile River DS Major Barrages,”. Springer International Publishing Switzerland . Hdb Env Chem, DOI 10.1007/698_2016_91.

[7] Sattar, A. and Raslan, Y. ,( 2014 ) ."Predicting Morphological Changes DS New Naga-Hammadi Barrage for Extreme Nile Flood Flows: A Monte Carlo Analysis," J. Adv. Res., vol. 5, no. 1, pp. 97-107.

[8] Foda ,A. and Sattar, A., (2013). " Morphological Changes In River Nile at Bani-Sweif For Probable Flood Flow Releases,". In: Proceedings Of The International Conference On Fluvial Hydraulics, RIVER FLOW 2014, Switzerland.

[9] Sattar, A., (2013) . "Using Gene Expression Programming To Determine The Impact Of Minerals On Erosion Resistance Of Selected Cohesive Egyptian Soils,". In: Experimental and Computational Solutions Of Hydraulic Problems, Part Of The Series GeoPlanet: Earth and Planetary Sciences, pp 375-387. 
[10] Sattar ,A., (2014).“Gene Expression Models For Prediction of DamBreach Parameters,". J Hydroinf vol 16 no.3, pp. 550-571. IWA.

[11] El-Hakeem M., Sattar A., (2015). "An Entrainment Model For Non-uniform Sediment. Earth Surf. Process Landf., vol 4 no.9, pp. 1216-1226. doi:10.1002/esp.3715.

[12] U.S. Army Corps Of Engineers. (1993). "River Hydraulics.” U.S. Army Corps Of Engineers Washington, 176.

[13] Delft3D-FLOW, User Manual. 2014.

[14] Carlos, P., Roberto, M., Mauricio,T., and Nestor,J., (2005), Modelling Of Flow In a Tidal Flat Area in The South-Eastern German Bight, Die Küste, 69 PROMORPH (2005), pp. 141-174.

[15] Chai, T. and Draxler, R. (2014) 'Root Mean Square Error (RMSE) or Mean Absolute Error (MAE) - Arguments against avoiding RMSE In The Literature', Geoscientific Model Development, pp. 1247-1250. doi: 10.5194/gmd-7-1247.

\section{مقارنة بين نموذجين رياضيين للتتبؤ بالتغيرات الهيدروليكية والمورفولوجية

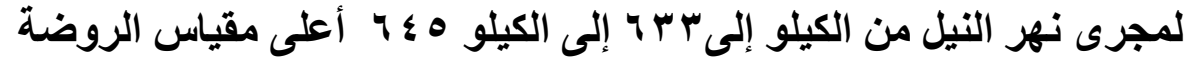

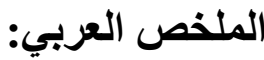

النماذج الرياضية اصبح لها دور فعال في در اسة حركة المياه فى الأنهار حيث تستخدم في محاكاة وتمثيل سريان التدفق المائي و تقييم التغير ات الهيدرولوجية و المورفولوجية بمجرى الانهار. الهدف من هذه الدراسة هو مقارنة وتحليل لنتائج تطبيق نموذج رياضى ثنائى الأبعاد (FESWMS) ونموذج (Delft 3D) لمحاكاة التغيرات في هي حركة المياه و الروسوبيات فى المجرى المائى وتقييم النتائج المستنتجة ووضع توصيات بتطبيقهما المستقبلي. تم تطبيق النموذجين على حبس من نهر النيل بطول بال كم فى

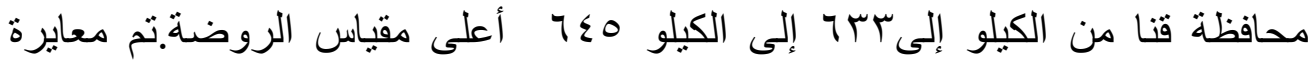
و التحقق من النموذجين الرياضبين من خلال تجميع البيانات المساحية والهيدرولوجية للمناسيب و التصرفات لعدد من السنوات المختلفة و تم التطبيق لعدد من السيناريوهات المختلفة ( التصرف الاقصى والادني لنهر النيل ) . تم إستتناج التغيرات الهيدرولوجية ( مناسيب سطح المياه و سرعة التيار المائي داخل المجرى) و التغير ات المورفولوجية ومن ثم تم عمل مقارنات بين نتائج النموذجين و البيانات الحقلية المقاسة فى منطقة الدر اسة. أوضحت نتائج هذه الدراسة بأن النموذج ثنائى الأبعاد (SMS) هو (كو

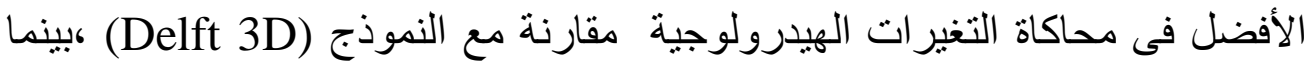
النموذج (Delft 3D) أثبت فعاليته فى محاكاة التغير ات المورفولوجية. 